\title{
The Nationalization of Legislative Collaboration: Territory, Partisanship, and Policymaking in Argentina
}

\author{
Ernesto Calvo | Associate Professor | University of Maryland | ecalvo@gvpt.umd.edu \\ Marcelo Leiras | Assistant Professor | Departamento de Ciencias Sociales | \\ Universidad de San Andrés | mleiras@udesa.edu.ar
}

\begin{abstract}
This paper analyzes the nationalization of collaborative policy efforts among lawmakers in Argentina. In doing so, we distinguish the nationalization of electoral competition and the nationalization of a legislator's policy intent. To measure the nationalization of legislative efforts, we assess the degree to which legislators collaborate with members of their party and members of their district in the drafting of legislative initiatives. We interpret the density of cosponsorship networks as indicative of legislative collaboration among legislators and estimate exponential random graph models (ERGM) to explain the partisan and territorial determinants of collaboration over a 25-year period. A study of 130,000 legislative initiatives proposed to the Argentine Congress from 1984 to 2007 shows district and partisan effects becoming more prominent over time. We also show that district and partisan effects are more pronounced at higher thresholds of cosponsorship collaboration.
\end{abstract}

Keywords. party nationalization, legislative nationalization, cosponsorship, network analysis, exponential random graph models, Argentina.

\footnotetext{
"I am not shortsighted. I believe in the electoral contract. I consider that when you represent a community, a district, an idea, you should honor them. I defend the interior provinces of this country by conviction, not because I am in the government or in the opposition." House Rep. Cristina Fernández de Kirchner (PJ, Santa Cruz), March 23, 2000, $3^{\text {rd }}$ Meeting, Argentine House, Discussion of Initiative 114-PE-99.

"Peronism is a national movement led by the President. The offer to the citizens is National. We are not a federation of provincial and municipal parties." Aníbal Fernández, chief of staff of President Cristina Fernández de Kirchner, April 15, 2011.
}

The analysis of party system nationalization has figured prominently in the agenda of comparative scholars for over half a century. Earlier studies saw party system nationalization as constitutive of wider modernization processes superseding traditional societies (Lipset and Rokkan 1967; Bendix 1977; Rokkan 1970). The resurfacing of nationalist political movements in Southern and Eastern Europe spurred interest in the subjective dimension of this phenomena and inspired a large literature in which the contributions of Anderson (1983), Gellner (1983) and Smith (1995) stand out. In the US, na- tionalization was the main subject of the protracted and fertile partisan realignment debate (elegantly discussed in Mayhew 2000) and a key ingredient explaining policy by responsible parties (Miller and Stokes 1962, 1963). More recently, research on the effect of majoritarian electoral rules on party system fragmentation has motivated a series of comparative studies on the determinants of party system nationalization (Alemán and Kellam 2008; Caramani 2004; Chhibber and Kollman 1998; Chhibber and Kollman 2004; Cox 1999; Jones and Mainwaring 2003; Leiras 2006; Morgenstern, Swindle, and Cas- 
tagnola 2009; Rodden 2010; Cox and Knoll 2003; Thorlakson 2009; Harbers 2010).

Arguably, the nationalization of party competition (and collaboration) counts as one of the most studied theoretical problems in the voting literature. The nationalization of parties' vote has been considered a prominent feature of modern electoral competition (Ziblatt 2009; Lipset and Rokkan 1967) and its absence arguably the culprit of a number of political ills such as inefficient policy implementation, substandard provision of public services, and clientelism (Jones 2005; Lago-Peñas and Lago-Peñas 2009). ${ }^{2}$

However, almost all research on the nationalization of party systems concentrates on describing and explaining the territorial distribution of a party's vote. In spite of the theoretical links connecting the nationalization of electorates and the implementation of policy (Bartolini 2000; Cusak, Iversen, and Soskice 2007; Iversen and Soskice 2006; Stepan 2004; Miller and Stokes 1962, 1963), few researchers have measured the degree of nationalization of the policy intent of parties and candidates. In particular, little attention has been given to the level of nationalization of lawmakers' collaborative efforts. As we will argue, electoral and legislative nationalization are distinct phenomena and should be studied as such. In this paper we explicitly address this gap in the literature and concentrate on exploring party system nationalization as reflected by the behavior of lawmakers in Congress.

To study the national orientation of legislative efforts, we consider the degree to which legislators collaborate with other members of their provincial delegation. ${ }^{3}$ To measure the nationalization of legislative efforts among lawmakers we focus on the study of cosponsorship networks in Congress, responsible for the drafting and promotion of law initiatives. We focus on the decision to coauthor or cosponsor bills as an indicator of the coordination efforts legislators make while in office (Alemán 2009; Crisp, Kanthak, and Leijonhufvud 2004), and inquire into the territorial orientation of such collaborative efforts.

We build upon a bourgeoning literature that in the past few years has sought to understand cosponsorship networks as expressions of public joint stances of policy preferences (Cranmer and Desmarais 2011; Alemán 2009; Alemán and Calvo 2013; Fowler 2006; Tam Cho and Fowler 2010). We consider cosponsorship networks as reflective of the policy intent of lawmakers, who connect with peers that share similar interests in policy areas or jurisdictions (Alemán and Calvo 2013); and measure the nationalization of legislators' policy intent as a function of the probability of coauthoring or cosponsoring legislation in Congress. To study these cosponsorship networks, we estimate exponential random graph models (ERGM) of legislative collaboration over 25 years of congressional politics in Argentina, distinguishing perso- nal, partisan, and district level effects as well as variations over time.

While we concentrate in the study of cosponsorship networks, there are a number of recent contributions that analyze the nationalization of the topics or jurisdictions proposed and debated by Congress, e.g., Chasquetti and Micozzi (2012). In this paper we do not analyze the level of nationalization of policy content in Congress. Instead, we show critical dimension of legislative behavior -cosponsorship that already provides good measures of nationalization/denationalization in Congress.

Using cosponsorship data, we seek to show there is a legislative dimension to nationalization which may be independent from its electoral manifestations. Secondly, we explore and briefly describe the ways in which the legislative and electoral dimensions of party nationalization may interact. At this early stage of theoretical exploration, we hold no clear expectation as to which combination of electoral and legislative nationalization we are more likely to observe, nor are we able to ascertain whether either of these two phenomena causes the other or they are both outcomes of a deeper cause. Instead, we present two distinct, relatively novel and increasingly demanding measures of legislative collaboration and apply them to the Argentine Congress.

Significant differences in socio-economic conditions distinguish the 24 provincial districts that compose the Argentine federation. However, no significant ethnic cleavage divides local constituencies and most politically relevant resources are concentrated at the national level, e.g., in the executive's office. Therefore, there are centripetal forces that would push Argentine politics towards nationalization as well as centrifugal ones that drive political behavior towards the provinces (Micozzi 2013). Indeed, Argentina has experienced both periods of relatively high electoral nationalization and denationalization since democratization in 1983.

Did legislative nationalization trends precede or follow electoral trends? Are the reasons that lead legislators to cooperate more frequently with colleagues elected in the same district similar to those that lead citizens of those districts to behave differently from residents of other provinces? The combination of socio-institutional traits and electoral outcomes of the Argentine cases provides us with a particularly propitious opportunity to answer these questions and carry our theoretical exploration forward.

The results in this article show that recent denationalization in electoral competition in Argentina has been accompanied by an increase in district level legislative collaboration. We find that partisan collaboration within districts outpaced collaboration across districts for all major parties in Argentina. Since democratization in 1983, the provincial party delegation (PPD) has become the prime determinant of policy 
design. The results provide a window into the process of legislative denationalization which complements recent scholarship on the territorial organization of party politics in Latin America (Calvo and Escolar 2005a; Leiras 2007a; Levitsky 2003; Gervasoni 2010; Díaz Cayeros 2006; Gibson 2005; Falleti 2010; Lodola 2009; Gibson and Suárez-Cao 2010).

\section{Nationalized Electoral Competition and Legislative Collaboration}

What is a nationalized political party? So far, the literature single mindedly focuses on electoral nationalization and offers two broad sets of answers to this question. The first one focuses on the relative homogeneity of voters' behavior, both across districts and over time. According to these theories, like voters behave alike, with nationalized electorates supporting or abandoning parties in concert. Thus a nationalized party is one that in every district caters to and receives votes from constituencies that share similar socio-economic traits and policy preferences. A nationalized electorate, consequently, is one that swings in similar direction and magnitude across districts and between elections (Morgenstern and Swindle 2005; Kawato 1987; Mayhew 2000; Alemán and Kellam 2008).

A second research tradition describes nationalization as the capacity of parties to amass comparable electoral returns, e.g., vote shares across districts. Nationalized parties, thus defined, compete in all electoral districts and gather comparable vote shares, often offering dissimilar policies to their local supporters (Jones and Mainwaring 2003; Chhibber and Kollman 2004).

Both approaches seek to capture nationalization of the party system in the electoral arena, the result of cultivating a nationalized constituency or of sound electoral performances across districts. However, the behavioral implications for legislators differ for each line of research. Indeed, while a nationalized electorate should be expected to strengthen the national orientation of the legislator's activities - and the nationalization of its collaborative efforts with fellow lawmakers - electoral success across heterogeneous districts can often require legislators to cater their policies to different local constituencies, and consequently to denationalize collaborative efforts in Congress. Because the protection of the party label remains a prime concern for party members (Cox and McCubbins 2005), strategies that maximize votes across heterogeneous districts may still find that lawmakers vote together on the plenary floor while coauthoring and cosponsoring bills with a more restricted group of fellow party members.

\section{Beyond the Responsible Party Model}

In this article we argue that electoral nationalization and the nationalization of legislative collaboration describe dimensions that are both empirically and theoretically distinct. Understanding how these two dimensions of party system nationalization interact is of critical importance.

A first dimension of nationalization, electoral nationalization, describes electoral traits shared across districts by parties and voters. This first dimension is explained by electoral data which describe parties successfully competing in all districts. As in the current literature, party system features are similar across the territory, with parties competing in all districts and catering to similar types of voters.

The second dimension, legislative nationalization, describes high rates of within-party and cross-district collaboration. In this second dimension, a party is nationalized because the behavior of within-district legislators from the same party is roughly similar to that of across-district legislators. In contrast, legislative denationalization occurs when legislators develop policy targets that are local, forging closer ties with fellow members from the region or district.

Conventional depictions of the responsible party model emphasize the importance of programmatic parties with high electoral and legislative nationalization (Bartolini 2000; Franzese 2002; Miller and Stokes 1962, 1963). Under the responsible party framework, representatives cultivate programmatic party labels that target categories of voters, irrespective of their territorial origin. Policy content with clear ideological markers that target nationalized electorates, in turn, results in cosponsoring and co-authoring of bills with fellow party members irrespective of their district membership.

As described by Miller and Stokes:
“Under a system of party government the vo- ters' response to the local legislative candidates is based on the candidates' identification with party programs. These programs are the subs- tance of their appeals to the constituency, whi- ch will act on the basis of its information about the proposals and legislative record of the par- ties. Since the party programs are of dominant importance, the candidates are deprived of any independent basis of support. They will not be able to build in their home districts an electoral redoubt from which to challenge the leadership of their parties." (Miller and Stokes, 1962: 533).

In the system of responsible parties, consequently, ambitious politicians organize to advance national programmatic goals. These national programmatic goals, expressed in a portfolio of legislative proposals, seek to cultivate voters according to functional rather than territorial criteria. The legislative behavior of members of Congress (MCs), consequently, is defined by collaboration with fellow members that are programmatically closer irrespective of their districts of origin. 
However, electoral nationalization can also occur when parties cultivate local voters, orienting their targets of legislation to distinct local constituencies while still supporting each other in congressional votes. For example, a party that competes in all districts may de facto legislate as a coalition of local electoral organizations, forging legislative majorities to deliver local goods.

Much of the literature on late $19^{\text {th }}$ century US politics, for example, describes both the Democrats and Republicans as a collection of distinct party machines dividing the "spoils" in Congress (Engstrom and Kernell 2005). When party majorities are forged to maximize legislative gains-from-exchanges and deliver local goods (Shepsle and Weingast 1995; Weingast 1989; Gilligan and Krehbiel 1994), within-district collaboration in the drafting of bills dominates the policymaking process. In such an environment, legislative majorities allow members to meet the demands of parochial constituencies with limited programmatic goals.

Tabela 1. Party Nationalization in Electoral and Legislative Arenas

\section{Electoral Nationalization}

\begin{tabular}{|c|c|c|c|c|}
\hline & & & High & Low \\
\hline \multirow{2}{*}{ 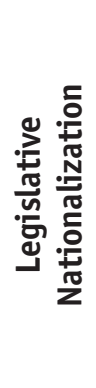 } & \multirow{2}{*}{ 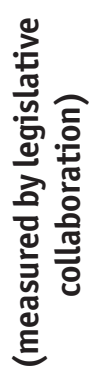 } & High & $\begin{array}{l}\text { Parties compete in all districts and } \\
\text { legislators collaborate with each other } \\
\text { irrespective of their district of origin } \\
\text { (Responsible Party Model) }\end{array}$ & $\begin{array}{l}\text { Parties compete in few districts and } \\
\text { legislators collaborate with each other } \\
\text { irrespective of their district of origin } \\
\text { (Segmented Party Model) }\end{array}$ \\
\hline & & Low & $\begin{array}{l}\text { Parties compete in all districts and a } \\
\text { parochial orientation of legislative } \\
\text { efforts. }\end{array}$ & $\begin{array}{c}\text { Parties compete in few districts and a } \\
\text { parochial orientation of legislative efforts } \\
\text { (Spoils Model) }\end{array}$ \\
\hline
\end{tabular}

In the gains-from-exchange model, consequently, legislators support fellow members when reporting initiatives from committee and vote for each other's proposals on the plenary floor. However, the development of local policy affinity drives party members to co-author and cosponsor initiatives with fellow members from their districts or regions. Legislative party blocs, consequently, act as a coordination device that facilitates exchanges between party members across districts. Meanwhile, policy drafting and cosponsorship remain locally bounded (Gilligan and Krehbiel 1994; Weingast 1989). As a result, the cosponsoring and co-authoring of bills could be denationalized even when party members coordinate their electoral strategies as well as their committee and floor behavior in Congress.

For example, in analyzing the formation of the Justicialista Party in Argentina, both Gibson (1997a) and Macor and Tcach (2005) note that strategic alliances with conservative provincial parties in its formative years ${ }^{4}$ resulted in a nationalized electoral party composed by a pro-labor metropolitan coalition and a conservative peripheral coalition. While the party successfully recruited voters in the whole of Argentina, the distinct programmatic origins of coalition members reinforced parochial legislative collaboration within districts and regions, denationalizing the drafting and cosponsoring of legislation.

The second column of Table 1 presents two scenarios of low electoral nationalization. The first one, in the top row, represents a case in which representatives of different districts cooperate in drafting legislation even though the party fails to compete in a significant number of districts. The formative years of Socialist parties in the late $19^{\text {th }}$ Century Europe, for example, were characterized by geographically constrained but programmatically oriented parties (Bartolini 2000; Cusak, Iversen, and Soskice 2007; Calvo 2009; Rodden 2010). Similar party developments characterized the formation of the UCR in the early $20^{\text {th }}$ century in Argentina, as well as the PRD and the PAN in Mexico. Constraints on the distribution of the party's vote, consequently, result in electorates that are functionally represented but territorially bounded.

Consequently, in segmented party models responsible parties cater to categories of voters but fail to successfully run candidates in a significant number of districts. Under these circumstances, the party faces a choice between expanding its core constituency and adapting its programmatic goals to accommodate the preferences of different local constituents. For example, it may advance the programmatic goals of its core supporters while targeting resources to a distinct group of local voters to advance broader electoral goals in marginal districts. Given that party constituents are unevenly distributed across districts, the electoral performance of the party seems denationalized. However, their legislative behavior should still respond to programmatic preferences, making it more likely that MCs will cooperate with fellow party members, irrespective of their districts of origin. For this reason, we label this scenario the segmented party model of nationalization.

The last scenario combines low electoral nationalization and parochial orientation of legislative incen- 
tives. Denationalized parties, both in performance and intent, target different policies to distinct district level voters. As in the gains from exchange model, the incentive to collaborate in the drafting and sponsoring of law initiatives is weak and electoral performance uneven, heavily dependent on the delivery of private and club goods to voters (e.g., the spoils model of legislative denationalization).

\section{Electoral and Legislative Denationalization in Argentina}

As described before, electoral and legislative party nationalization describe different phenomena. When electorally minded parties compete for the preferences of local voters with different preferences, legislative collaboration - and targets of policy - may vary even among parties with solid performances in all districts. As discussed by Gibson (2005), policies that shelter districts from nationwide electoral shocks can both improve electoral performance and denationalize policy goals.

Gains from exchange, with parties targeting different district level voters, are difficult to materialize. Coordination bottlenecks may hinder effective logrolling and, more importantly, different preferences across districts can lead to the predominance of clientelistic linkages in some regions and programmatic ones in other regions. Additionally, when agenda-setting powers reside with executives, as they do in Latin American democracies, presidents may exploit the parochial orientation of legislators, buying the legislative votes of representatives of "low maintenance" constituencies (Gibson, Calvo, and Falleti 2004) without compromising the integrity of their policy programs (Cox and Morgenstern 2002). This would bias the distribution of excludable goods to some regions and thus conspire against the ability of the party to simultaneously satisfy the particularistic needs of different districts. Under these circumstances, we expect to observe that a decline in electoral nationalization leads to a reduction in legislative nationalization.

As several works document (Calvo and Escolar 2005b; Leiras 2007b; Gibson and Suárez-Cao 2007), the Argentine party system has recently experienced a process of denationalization at the electoral level. Varying distributions of policy preferences across districts and biased allocation of resources from the national government (Gibson 1997b; Calvo and Murillo 2004) have been documented to characterize the Argentine electoral arena and the strategies of Argentine governments. An analysis of this case may thus be suitable to explore the wider political implications of this electoral phenomenon.

Table 2. Party Nationalization in Argentina, 1984-2008

Electoral Nationalization

High

Low

\begin{tabular}{|c|c|}
\hline High & $\begin{array}{l}\text { Responsible Party Model } \\
\qquad \text { PJ (1984-1991) } \\
\text { UCR (1984-1991) }\end{array}$ \\
\hline \multirow[b]{2}{*}{ Low } & Gains-From-Exchange Model \\
\hline & $\begin{array}{l}\text { UCR (1991-2001), } \\
\text { PJ (1991-2007) }\end{array}$ \\
\hline
\end{tabular}

Segmented Party Model

Frepaso, PI, U.Ce.De., PRO

\section{Spoils Model}

UCR (2001, 2007), municipal and provincial Parties (MPN, FR, BSJ, Demócrata, MPJ)*

Note: There are a large number of provincial parties in Argentina. Those reported in Table 2 are good examples of such parties rather than an exhaustive list.

Our approach considers the collaborative efforts of lawmakers and seeks to distinguish national or district level content of congressional networks. ${ }^{5}$ As already stated, we consider legislative nationalization to be separate from electoral nationalization, and consider that different institutional and electoral mechanisms drive political systems to nationalize in each domain. Our view highlights these different mechanisms, understanding that effective political parties must solve collective action problems and reduce transaction costs among their members. Because electoral and legislative coordination pose different challenges to politicians, we expect nationalized legislative parties and nationalized electoral parties to require different types of political investment. Hence, a nationalized legislative party is one that promotes cooperation among legislators regardless of the constituencies they represent. 


\section{Other Mechanism Disengaging Legislative and Electoral Nationalization}

In the previous section we showed that within the electoral connection framework (Mayhew 1974) there are good reasons to distinguish legislative from electoral nationalization. Electorates with distinct territorial preferences could still be represented by legislative institutions that are nationalized. Emerging parties that are locally bounded often behave as programmatic national parties. Therefore, we argued, it is important to distinguish the mechanisms that facilitate electoral and legislative nationalization.

There are also a number of other mechanisms that can result in a de-nationalized electorate with a nationalized orientation of legislators' behavior. ${ }^{6}$ For example, strong executives facing weakly institutionalized parties often dominate the legislative process, advancing national legislative agendas that supersede territorial incentives, as was common in the rise of Juan Domingo Peron, Lazaro Cardenas, and -to a lesser degree - Getulio Vargas.

Similarly, there is a significant literature showing that agenda setting prerogatives and the control of the legislative gates can dominate the issues discussed, amended, and voted in a legislature. Both in Chile and Brazil, for example, the executive has a direct hand on the legislative gates, resulting in nationalization of legislative behavior on critical issues such as budget, induced by the control of the agenda and the exclusive rights of a national authorities in key jurisdictions (Pereira and Mueller 2004; Alemán 2006; Alemán and Navia 2009).

\section{Legislative Networks and the Nationalization of the Political System}

As described at the beginning of this paper, many authors have analyzed the determinants of electoral nationalization. In contrast, very little effort has been directed to understand legislative nationalization. To measure the nationalization of legislative collaboration, we take advantage of recent advances in the study of cosponsorship networks. In Argentina, members of Congress routinely cosponsor legislation with fellow representatives, signing on each other projects to indicate support and to claim credit among voters. Almost half of initiatives proposed to Congress are signed by more than one representative, signaling joint stances on issues.

A number of authors have shown that cosponsorship data carry significant information, which can be used to estimate the preferences of legislators and the determinants of policy networks (Fowler 2006; Cranmer and Desmarais 2011).

Since 1984, the average density of Argentina's cosponsorship networks - e.g., the proportion of actual ties over all possible ties - is 0.296 , with a minimum of 0.14 during the first Congress after democratization and a maximum of 0.4 during the 1997-1999 Congress. ${ }^{7}$ The mean number of cosponsors is 4.63 with a median of 4 . As shown in Table 1 , over $91 \%$ of legislative initiatives have fewer than nine cosponsors.

Table 3. Number of Cosponsors per Bill, Argentine House, 1984-2007

\begin{tabular}{cccc}
\hline Number of Cosponsors & Frequency & Percent & Cummulative \\
\hline 2 & 14,658 & 28.82 & 28.82 \\
\hline 3 & 9,482 & 18.65 & 47.47 \\
\hline 4 & 6,989 & 13.7 & 61.18 \\
\hline 5 & 5,414 & 10.65 & 71.82 \\
\hline 6 & 3,858 & 7,59 & 79.41 \\
\hline 7 & 2,751 & 5.41 & 84.82 \\
\hline 8 & 2,033 & 4 & 88.82 \\
\hline 9 & 1,476 & 2.9 & 91.72 \\
\hline 10 & 1,139 & 2.24 & 93.96 \\
\hline 11 & 846 & 1.66 & 95.62 \\
\hline 12 & 621 & 1.22 & 96.84 \\
\hline 13 & 511 & 1 & 97.85 \\
\hline 14 & 460 & 0.9 & 98.75 \\
\hline$>15$ & 632 & 1.23 & 99.83 \\
\hline Total & 50,852 & 100 & 100 \\
\hline
\end{tabular}

Note: Data from the Secretaría de Información Parlamentaria, Argentine Congress. 
To measure the nationalization of cosponsoship networks in Argentina, we take advantage of recent statistical advances to model complex relational data. We model the determinants of cosponsor-

$$
P\left(y_{i j} \mid X\right)=\exp \frac{\left[\Theta^{T} g\left(y_{i j}, X\right)\right]}{k(\theta)}
$$

ship ties using exponential random graph models (ERGM), which explain the probability of observing a tie between two members $[i, j][i, j]$ while accounting for social structure in relational data (Handcock et al. 2003; Robins et al. 2007). The dependent variable of our analyses is the observed tie or relation (edge) between each pair of actors or legislators (node). 8 For each distinct pair of members $i$ and $j$, the random variable yij takes the value of 1 if there is a tie and 0 otherwise. The probability of observing a tie is:

where $\mathrm{X}$ is a matrix of attributes associated with the actors (nodes) or ties (edges) in the network; $g\left(y_{i j}, X\right)$ is a vector of network statistics, $\theta$ is a vector of coefficients, and $k(\theta)$ is a normalizing constant. ${ }^{9}$

\section{Dependent Variable}

Unlike other types of relational data such as friendship or group membership, cosponsorship networks provide information both about the existence of a relationship and the relative frequency of such relationship (Alemán and Calvo 2013). Because the counts observed in cosponsorship data are meaningful, it is important to take advantage of such data rather than just assume away differences by reducing all counts to a single value expressing a tie.

Following Aleman and Calvo (2010) and Cranmer and Desmarais (2011), we take advantage of this extra information by transforming the original valued matrices into synthetic data reflecting layers of the networks.${ }^{10}$ We conduct two different types of analyses that extract information on the frequency of reported ties: first, we (i) augment our data using synthetic draws from the observed frequencies of ties in the original network of cosponsors (Alemán and Calvo 2013). As more frequent ties in the original affiliation matrix increase the probability of observing a tie in the synthetic data, we bootstrap ERGM estimates from 1000 network draws and retrieve estimates of the model. ${ }^{11}$ Our bootstrapped ERGM estimates, consequently, weigh more heavily those ties between pairs of legislators which occur more frequently.

As a second strategy to account for differences in the observed frequency of ties is to (ii) thin down the original data into multiple cross-sections of the network (Cranmer and Desmarais 2011), progressively increasing the number of cosponsored initiatives that are required to report a tie. As we thin down the original cosponsorship data, ERGM estimates provide information on the more active pairs of legislators. This allows us to observe the determinants of more intense or frequent cosponsorship activity.

\section{Independent Variables}

We include a number of edge and node covariates as predictors of cosponsorship in the Argentine Congress. To test the effect of shared identity traits, we include covariates for shared party membership, shared government/opposition membership, shared district, contiguous provinces, and shared committee membership. We expect that members who belong to the same party will be more likely to agree on their policy preferences and more likely to interact frequently to disclose their law initiatives. Consequently, shared partisanship should increase the likelihood of observing a tie between pairs of legislators. Other terms that describe homophile traits, such as being a member of the government or belonging to the same district, should also result in higher cosponsorship. However, we expect lower network effects when parties are nationalized and, consequently, within-party factions that cut across provinces become a more important determinant of policy collaboration. To this end, we also include a term interacting the district and party variables, allowing us to assess within- and across-district collaboration by members that belong to the same party. Other controls distinguish first-time legislators and the customary edge parameter, which serves as a constant in exponential random graph models.

Model specification follows existing usage, testing for homophily for those terms that explain shared traits (party, province, region, and committee) and defining as node covariates those variables that describe individual MC traits (freshman). Models are estimated for each of the 12 congresses (two-year periods) between 1984 and 2007.

\section{Results}

The results of the bootstrapped specifications are presented in Table 3, which presents median ERGM coefficients from 1000 synthetic networks drawn from the original data for each of the twelve Congresses after democratization. The results show party and provincial memberships as important determinants of legislative collaboration (joint effects).

As shown in Table 3, Peronist co-membership increases collaboration in all congressional periods but one, 1984-1985, when a major split between the old party guard and the "Renovadores" led to a sharp realignment among Peronist elites. Similarly, UCR co-membership increases collaboration among lawmakers in all periods but one, 19901991, the aftermath of the hyperinflationary crisis that led to the resignation of then President Raul R. Alfonsín. An intensely partisan period also see- 
ms to emerge in the aftermath of the 2001 crisis, with shared membership in the PJ and the UCR leading to significantly more intense collaboration. Shared provincial membership is an equally strong predictor of collaboration among lawmakers, with substantively and statistically significant coefficients in all but one period, 1986-1987. Particu- larly noteworthy is the increasing importance of provincial co-membership as a determinant of collaboration since 1998 . These results strongly support extensive narrative accounts of the consistent territorialization of party politics since the beginning of Carlos S. Menem's second administration (1995-1999).

Table 3. Exponential Random Graph Models on Synthetic Data, Bootstrapped Estimates, Argentine Cosponsorship Networks, 1984-2007

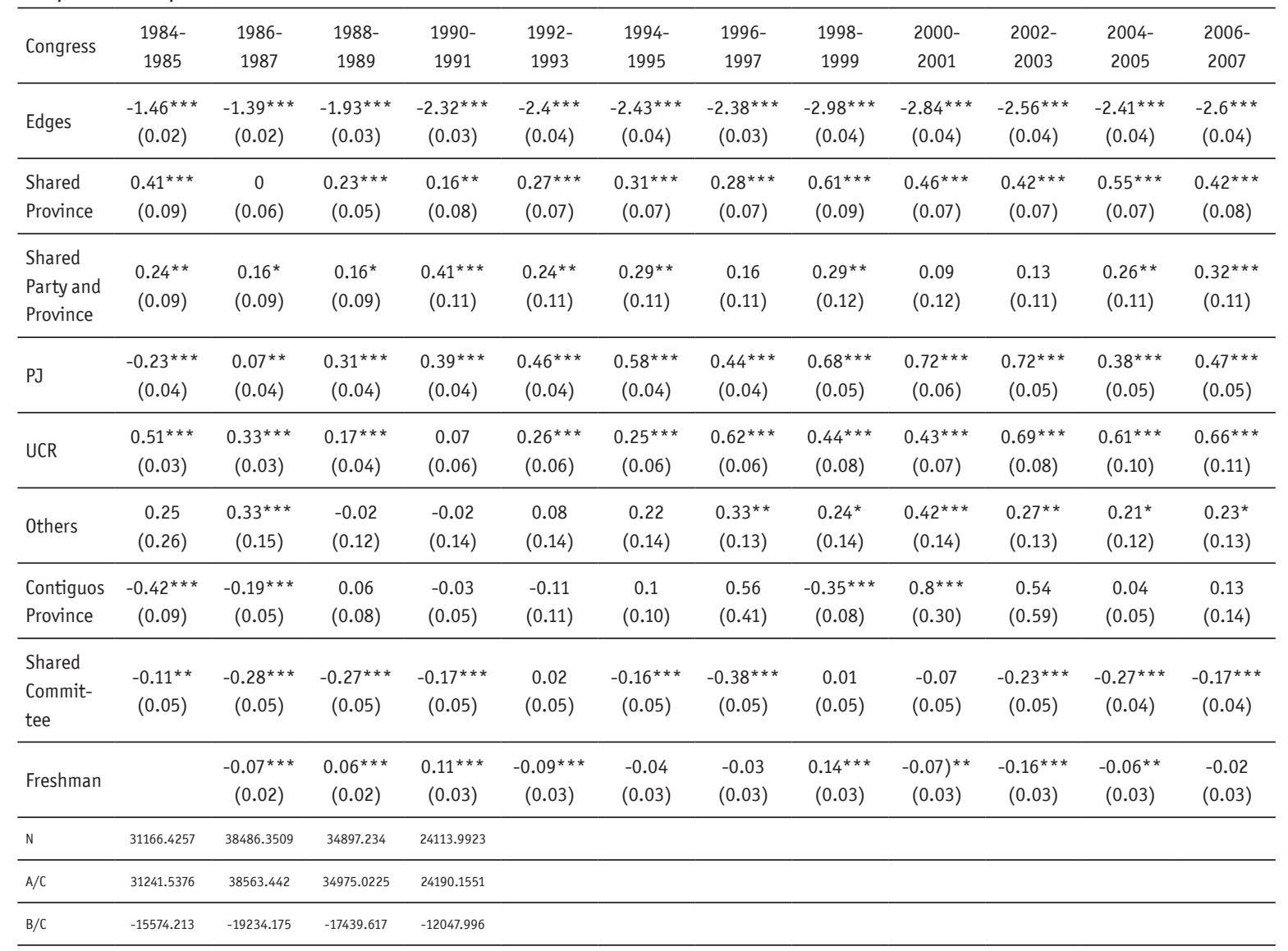

Note: Bootstrapped exponential random graph models reporting changes in the log-odds ratio of observing a cosponsorship network tie. Positive (negative) coefficients represent more (less) likely observable ties. The magnitude of the coefficient represents the "strength" of the effect.

Figure 1. Evolution of Estimates Explaining Cosponsorship Networks in Argentina, 1984-2007
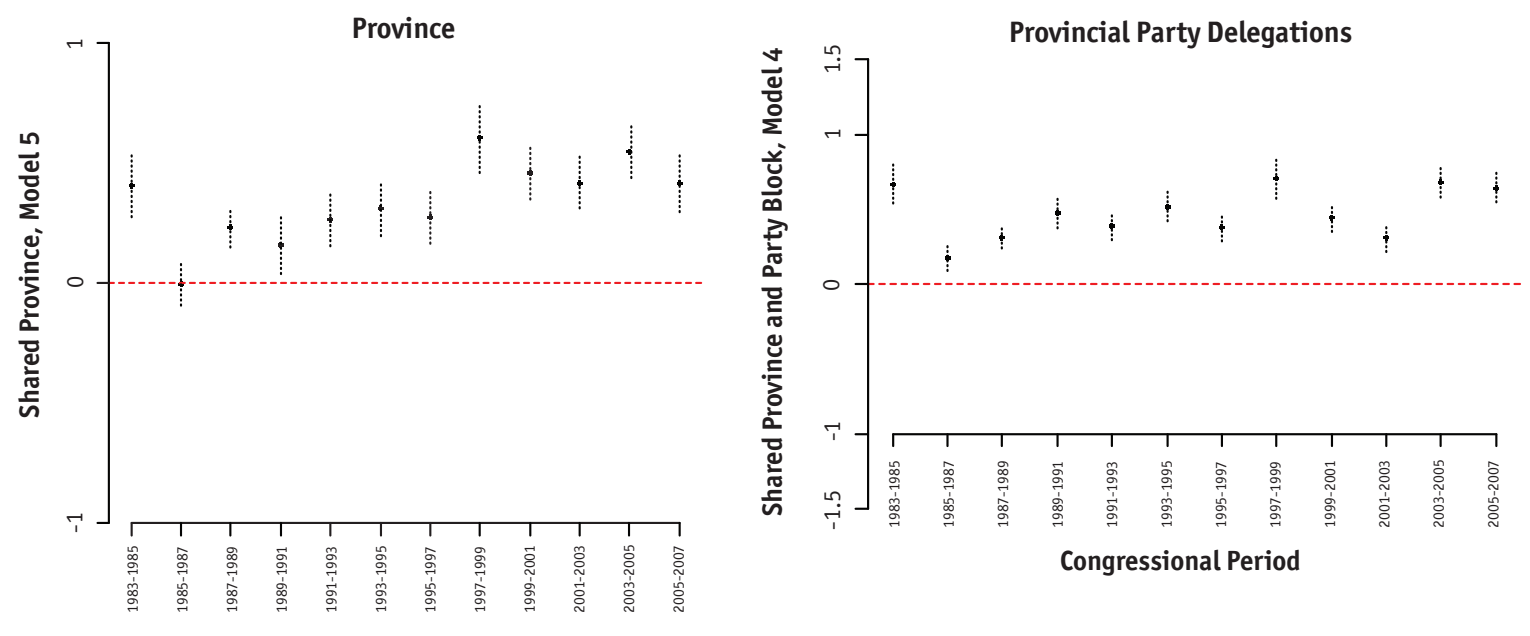

Congressional Period 

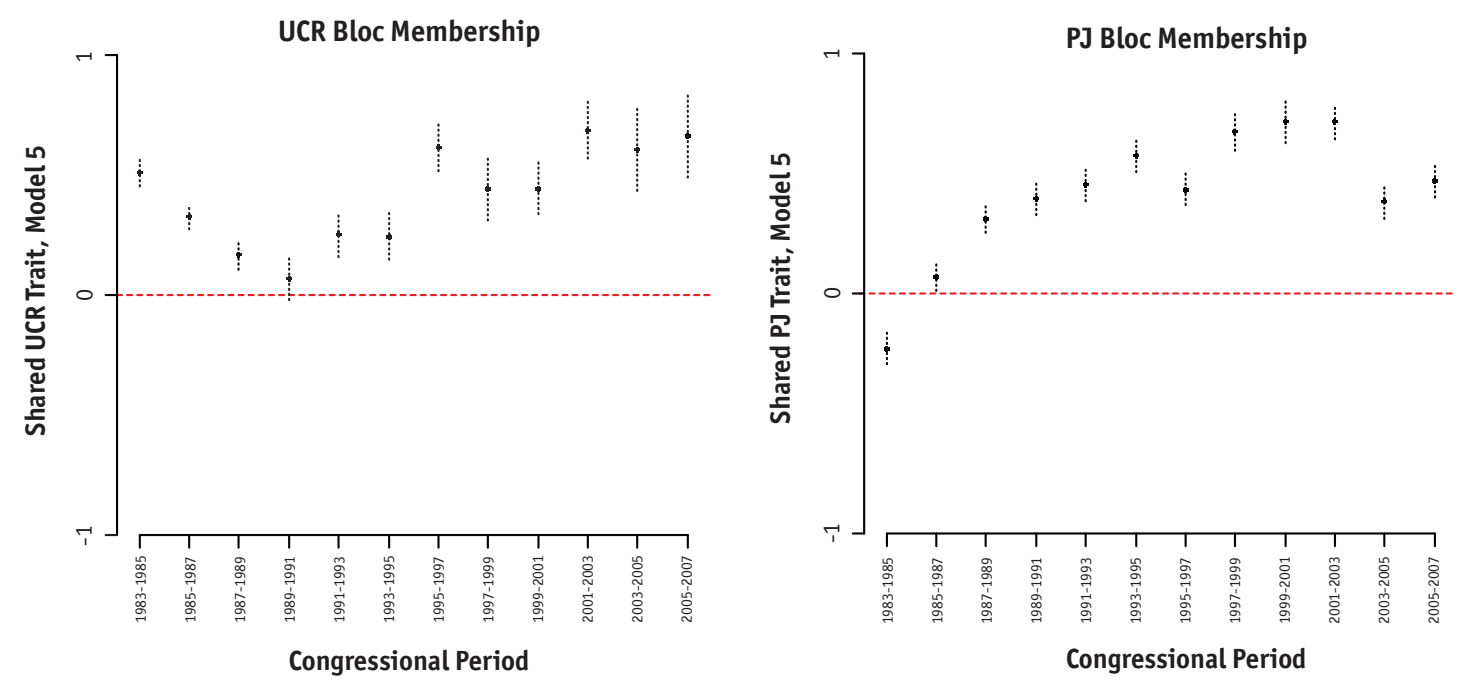

Note: Bootstrapped exponential random graph estimates reporting the independent variables' contribution to changes in the log-odds ratio of observing a cosponsorship network tie.

To better visualize and compare the results, we plot our bootstrapped coefficients in Figure 1, displaying the importance of shared provincial membership (upper left), the importance of shared province and party (upper right), and the importance of shared membership in the Peronist PJ (lower left) or the UCR (lower right). As can be seen, estimates of the 19841985 Congress are somewhat exceptional. This corresponds to two distinctive features of this first post-democratization Congress: first, this first Congress saw considerably more limited legislative activity than subsequent Congresses. Much legislation in this first Congress was initiated by the national executive in order to deal with the institutional and socio-political demands of the transition process. Second, this first democratic congress saw a party realignment within the Peronists, with the emergence of the "Reno- vadores" challenging the old guard both in Congress and in the electoral arena. The result was a decline in within-PJ cosponsorship paired with a significant increase in within-district cosponsorship.

We observe both more significant within-party and within-district collaboration over time. Particularly high district and party level effects are observed after the 1997, in spite of the decline in within-PJ cosponsorship after the realignment of 2005 .

Figure 2 presents the estimates of co-membership in a party and province (provincial delegation). The joint effect of province and party have become more pronounced over the past 20 years, supporting extensive narratives of the increasing importance of district level politics in Argentina.

Figure 2. Shared Partisan and Provincial Membership as a determinant of legislative Collaboration, PJ and UCR Delegations, 1984-2007
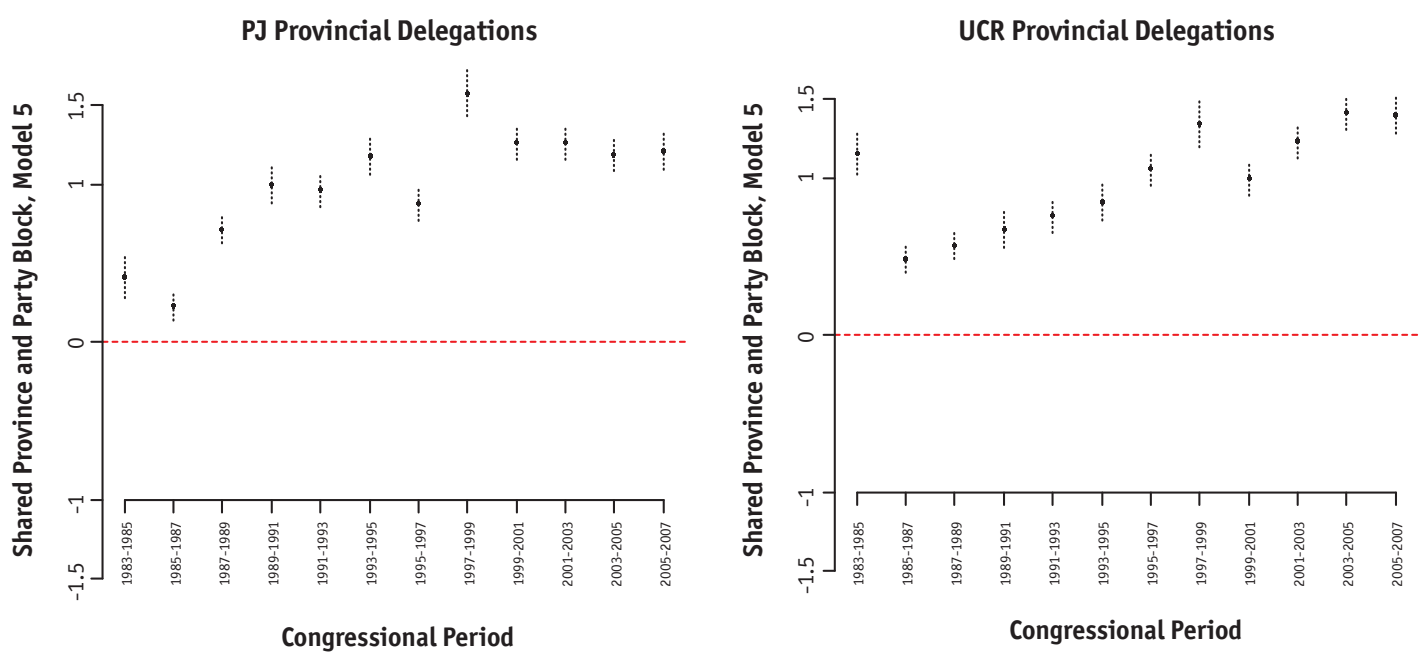
More prominent partisan and district level effects are also described when analyzing cosponsorship in individual provinces, as in Figures 3 and 4. In all five of the largest provinces (Buenos Aires, CABA, Cordoba, Santa Fe, and Mendoza), within-district collaboration has consistently increased since democratization in 1984. The relatively smaller delegations of a majority of provinces, which elect only five and seven members, have wider confidence intervals and display a more erratic collaboration pattern.

Figure 3. Cosponsorship Networks in Argentina, 1984-2007, Shared District Membership by Congressional Year, Selected Provinces

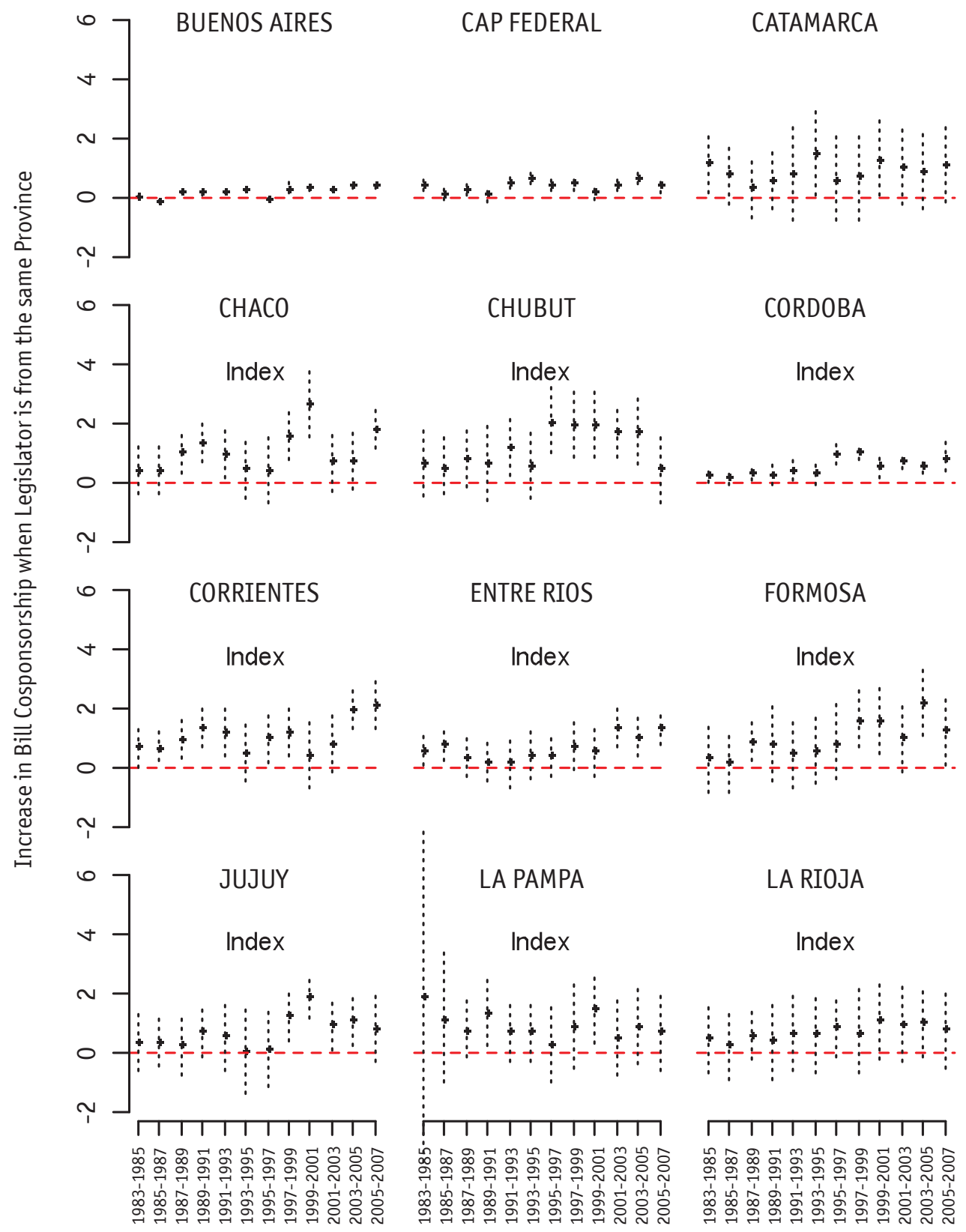


Figure 4. Cosponsorship Networks in Argentina, 1984-2007, Shared District by Congressional Year, Selected Provinces

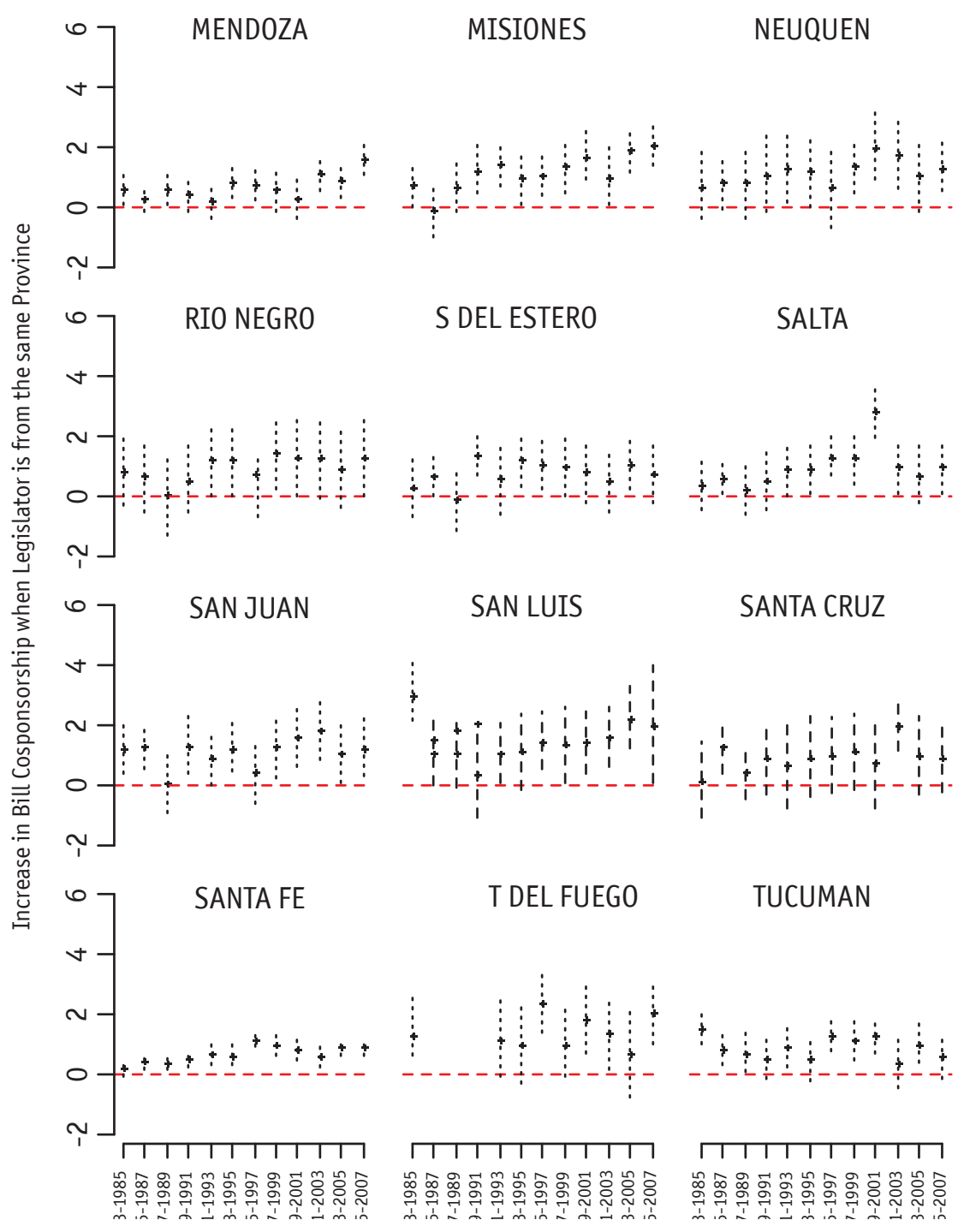

\section{Analyzing the Determinants of Higher Level Cosponsorship}

In the previous analyses, we estimated the average effect of shared partisanship and district membership on legislative collaboration. We showed more prominent partisan and provincial effects over time, for the average member of Congress irrespective of their actual level of collaboration. However, as described before, the valued matrix that describes cosponsorship activity also provides information to distinguish high-level collaborators and compare their behavior to that of low-level collaborators. For example, we may find that most legislators have cosponsored at least one bill with every member of their party, which would result in a very dense and unninformative network. However, we may find that members are more selective when considering high numbers of reported ties. To this end, Cranmer and Desmarais (2011) propose to thin down very dense networks by estimating ERGM models using different tie thresholds.

An example of the different networks observed by thinning the cosponsorship data successively is shown in Figure 5. The upper left plot describes a network that requires at least two bills to report a tie. As can be observed, the network is very dense, as most legislators cosponsor at least two bills with a large number of fellow MCs. As we elevate the threshold to a more demanding level, requiring, say, at least six bills to be cosponsored to report a tie (Figure 5, upper right plot), we observe a smaller network with considerably more structure. We see further separation across parties. In this second plot, smaller third parties are not mixed in the PJ and UCR networks. 


\section{Bloc Network, Congress 112, Thin 2}

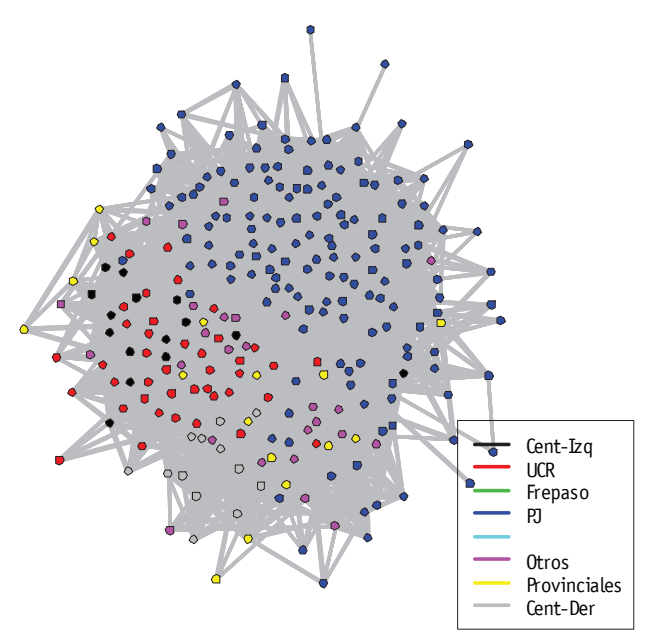

Bloc Network, Congress 112, Thin 12
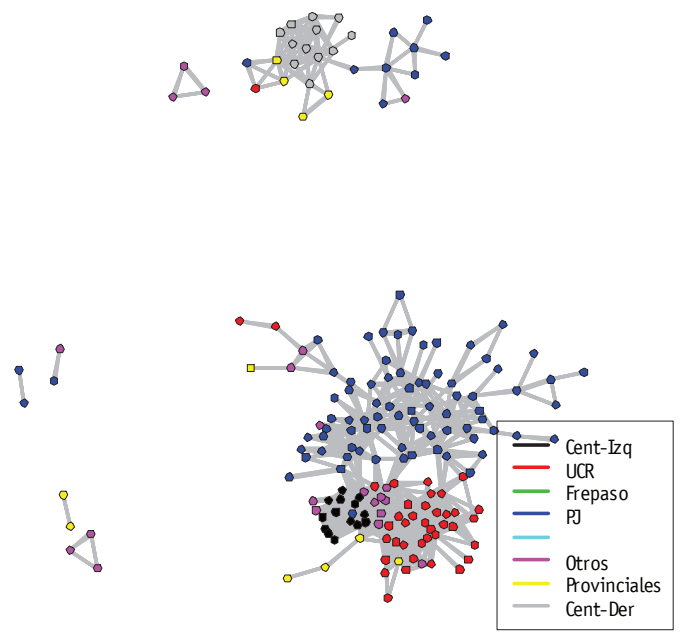

\section{Bloc Network, Congress 112, Thin 6}

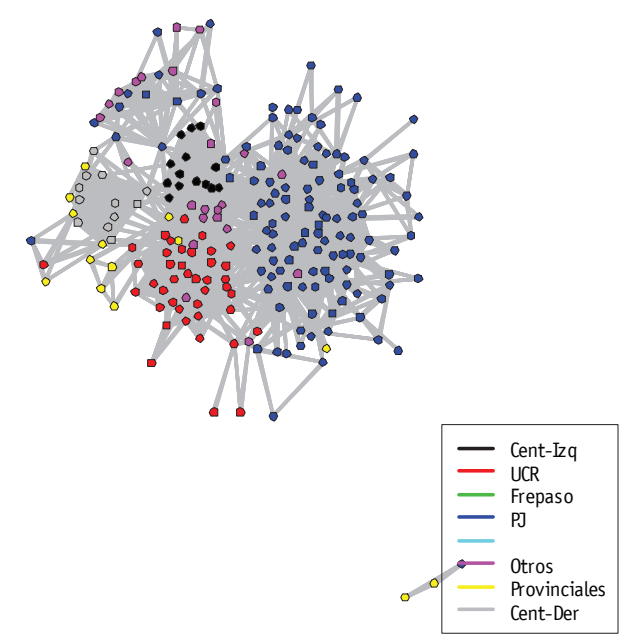

Bloc Network, Congress 112, Thin 18
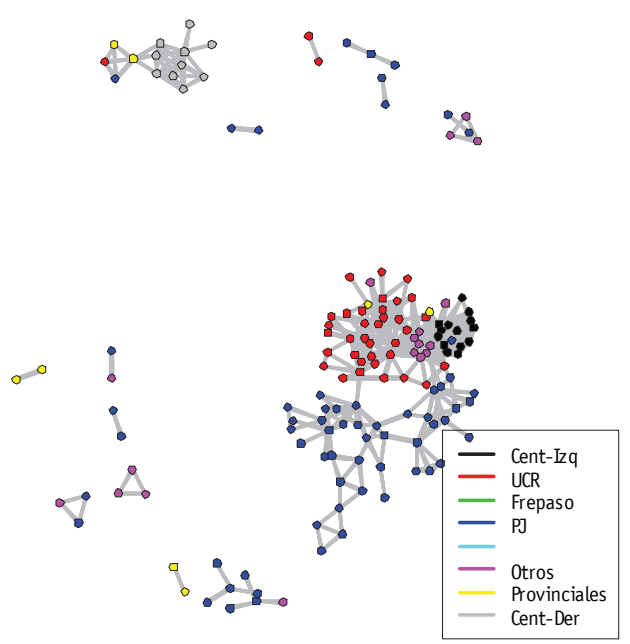

Note: Estimated using data from Información Parlamentaria, Argentine Congress.

Instead, we observe well-defined local (provincial) parties $^{12}$, parties on the left, on the right, as well as significant clustering among members of the $P J$ and the UCR. In analyzing this second plot, we see that at higher levels of collaboration, the partisanship effects are stronger. Further thinning the cosponsorship network, requiring 12 bills (Figure 5, lower left) or 18 bills (Figure 4, lower right) to report a tie, we see separate networks for the provincial parties. A larger network comprises the $\mathrm{PJ}$, the UCR, and a small group of center-left parties.

Figure 5 should illustrate how thinning allows us to observe higher levels of the cosponsorship network. By estimating exponential random graph models at each of the different thinning stages, consequently, we can assess how important partisan and district level effects are as we move from mapping single ties to mapping high activity cosponsorship.

To model high level cosponsorship activity, we run 20 different models for each Congress, each of them increasing the number of cosponsored bills that are required to report a network edge or tie. Rather than providing tables with the estimates for all 200 models, ${ }^{13}$ Figure 6 describes the linear estimates of shared province on cosponsorship at each level of thinning and for each of the 12 Congresses. The models are extremely robust, showing an increase on the importance of shared provincial membership explainign cosponsorship as the 
threshold increases. That is, as we analyze more active cosponsors, the importance of shared province increases signficantly.

Much more dramatic is the effect of shared party and province (provincial delegation) on cospon- sorship, as the level of activity increases. As shown in Figure 7, the effect of shared province and party on the probability of observing a network tie increases from around 0.5 in very dense networks to around 3 when at least 20 cosponsorship projects are required to observe a tie.

Figure 6: Provincial Effects on Cosponsorship Networks by Intensity of the Tie (Thinning), 1984-2007, Shared District by Congressional Year

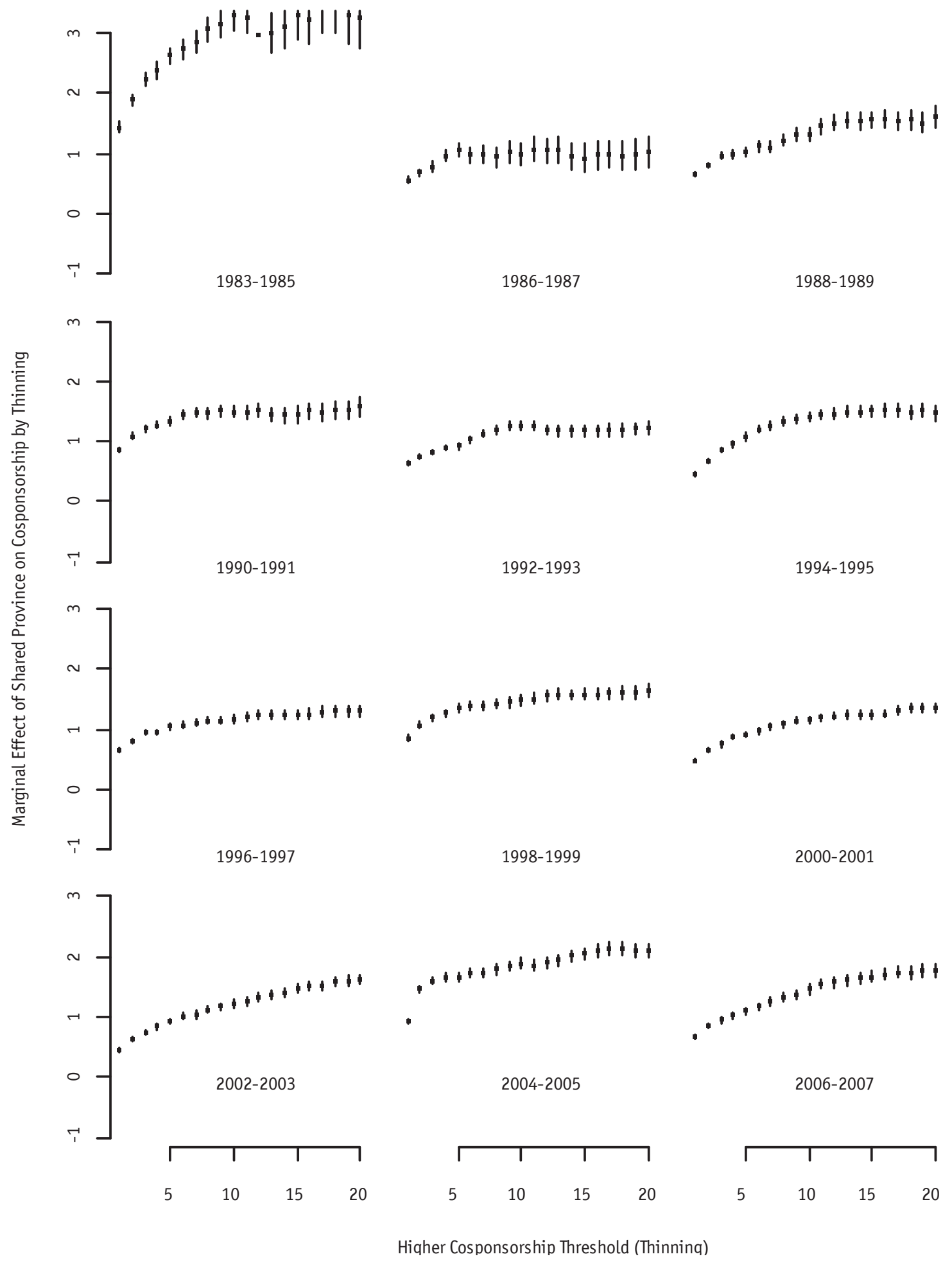


Figure 7: Cosponsorship Networks in Argentina by Intensity of the Tie (Thinning), 1984-2007, Shared Provincial Delegation (District and Party) by Congressional Year
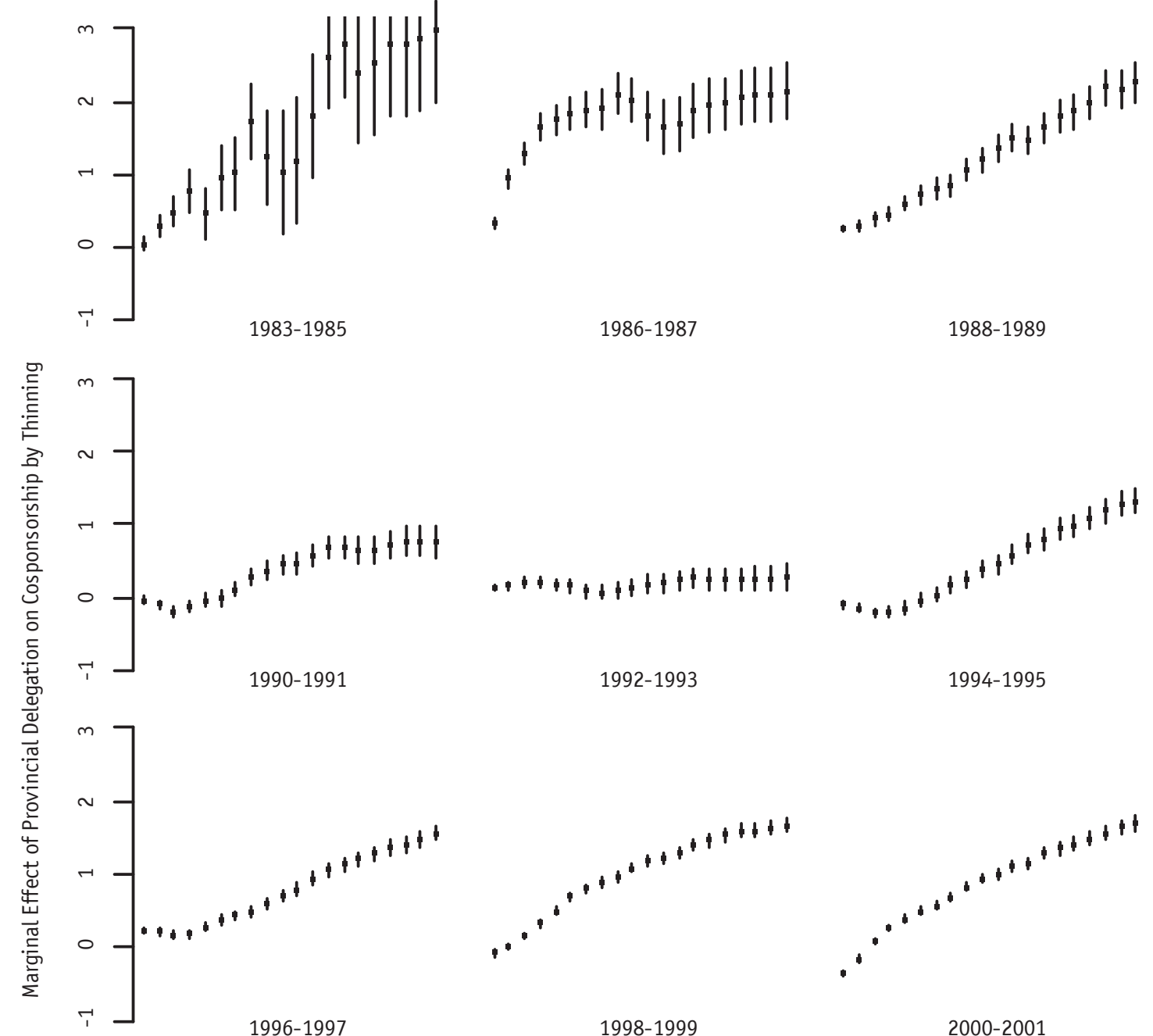

$\ldots+1+1+1+1+1+H+1+1$

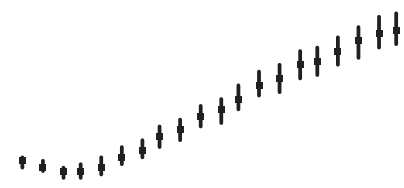

$1992-1993$

1994-1995
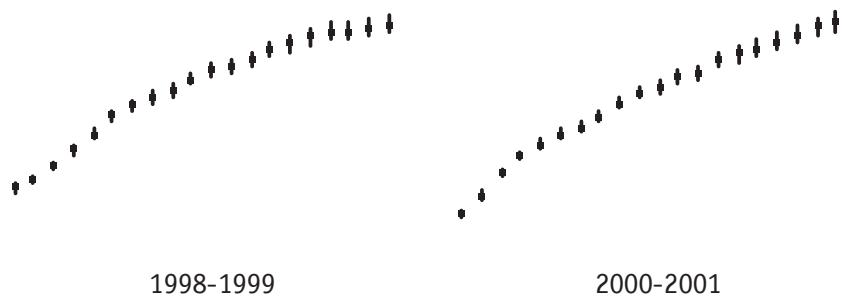

2000-2001
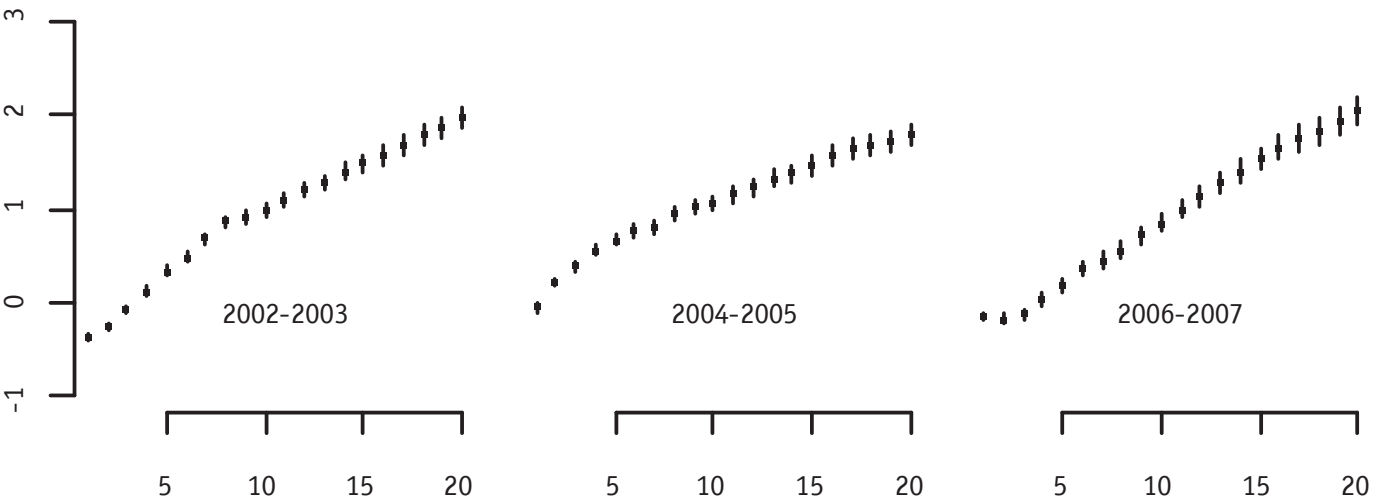

Higher Cosponsorship Threshold (Thinning)

\section{Concluding Remarks}

Until recently, the territorial roots of policy collaboration have been a blind spot of contemporary theories of party system nationalization. Striving to fill this conceptual gap, comparative studies of party nationalization have focused on the geographical variation of political preferences and the electoral behavior of voters. However, the conceptions they advance yield different predictions about the translation of this variation into legislative outcomes. Homogeneity of electoral sup- port across districts could occur, we argue, because parties represent constituencies with similar preferences but also because they simultaneously satisfy constituencies with different views and needs. The same goal, electoral nationalization, can be achieved through different legislative organizations: a responsible party with frequent cross-district collaboration, if district level preferences are similar; or an effective vote-trading machine, with less frequent collaboration, if they are different. The important substantive point to stress is that electoral nationalization does not always 
indicate nationalization of policy intent. Electoral nationalization may result from the effective combination of several territorially targeted initiatives. In other words, a complete portrayal of nationalization as a political phenomenon needs to incorporate a heretofore overlooked dimension: legislative nationalization.

Electoral and legislative nationalization are conceptually independent. They are also theoretically related. Logrolling imposes high costs on political transactions and a heavy burden on fiscal resources. Therefore, gains from trade models may be difficult to sustain. Geographically circumscribed targeting strategies may be more efficient when electoral performance is uneven across districts and clientelistic linkages predominate. Under these circumstances, we expect reductions in electoral nationalization to strengthen provincial cosponsorship networks and thus lead to a reduction in legislative nationaliza- tion.

The results of our study of legislative collaboration over 12 congressional periods in Argentina are largely consistent with this hypothesis. Shared provincial membership has been a strong predictor of legislative collaboration in almost all periods, but is has become more significant since 1998, when according to recent studies the Argentine party system started to show the first signs of political territorialization. More significantly, the joint impact of party and provincial effects on legislative collaboration has consistently increased as electoral nationalization declined.

Our study also identifies significant variation across parties, provinces and periods. This suggests that other factors, whose identification demands further theoretical work, filter the influence of electoral trends on the structure of legislative collaboration.

\section{References}

Alemán, Eduardo. 2006. "Policy Gatekeepers in Latin American Legislatures." Latin American Politics \& Society no. 48 (3):125-155.

. 2009. “Institutions, Political Conflict, and the Cohesion of Policy Networks in the Chilean Congress, 19612006." Journal of Latin American Studies no. 41 (3):467-491.

Alemán, Eduardo, and Ernesto Calvo. 2013. “Explaining Policy Ties in the Argentine and Chilean Congresses: A Network Analysis of Bill Initiation Data " Political Studies no. 64 (1).

Alemán, Eduardo, and Marisa Kellam. 2008. "The nationalization of electoral change in the Americas." Electoral Studies no. 27 (2):193-212.

Alemán, Eduardo, and Patricio Navia. 2009. “Institutions and the Legislative Success of 'Strong' Presidents: An Analysis of Government Bills in Chile." The Journal of Legislative Studies no. 15 (4):401 - 419.

Anderson, Benedict. 1983. Imagined Communities: reflections on the origins and spread of nationalism. London: Verso.

Bartolini, Stefano. 2000. The political mobilization of the European left, 1860-1980: the class cleavage, Cambridge studies in comparative politics. Cambridge ; New York: Cambridge University Press.

Bendix, R. 1977. Nation-building and citizenship: studies of our changing social order. Berkeley: University of California Press.

Calvo, Ernesto. 2009. “The Competitive Road to Proport ional Representation: Partisan Biases and Electoral Regime Change under Increasing Party Competition." World Politics no. 61 (2):254-295.

Calvo, Ernesto, and Marcelo Escolar. 2005a. La nueva politica de partidos en la Argentina : crisis politica, realineamientos partidarios y reforma electoral, Coleccion Democracia, partidos y elecciones. Buenos Aires: Prometeo : Pent. . 2005b. La nueva política de partidos en la Argentina: crisis política, realineamientos partidarios y reforma electoral. Buenos Aires: Prometeo / Pent Fundación para la Integración de la Argentina en el Mundo.

Calvo, Ernesto, and Maria Victoria Murillo. 2004. "Who Delivers? Partisan Clients in the Argentine Electoral Market." American Journal of Political Science no. 48 (4):742-757.

Caramani, Daniele. 2004. The nationalization of politics: the formation of national electorates and party systems in Western Europe. Cambridge: Cambridge University Press.

Chasquetti, Daniel, and Juan Pablo Micozzi. 2012. The Subnational Connection in Unitary Regimes: Progressive Ambition and Legislative Behavior in Uruguay. In 6th Congreso Latinoamericano de Ciencia Política. Quito, Ecuador.

Chhibber, Pradeep K., and Ken W. Kollman. 2004. The formation of national party systems: Federalism and party competition in Canada, Great Britain, India and the United States. Princeton: Princeton University Press.

Chhibber, Pradeep, and Ken Kollman. 1998. “Party Aggregation and the Number of Parties in India and the United States." The American Political Science Review no. 92 (2):329-342.

Cox, Gary. 1999. "Electoral rules and electoral coordination." Annual Review of Political Science no. 2:145-161.

Cox, Gary, and Jonathan Knoll. 2003. Ethnes, fiscs and electoral rules: the determinants of party-system inflation. Paper read at 2003 Annual Meeting of the American Political Science Association, August 28-31, at Chicago.

Cox, Gary, and Matthew McCubbins. 2005. Setting the Agenda: Responsible Party Government in the US House of Representatives. New York: Cambridge University Press. 
Cox, Gary, and Scott Morgenstern. 2002. “Epilogue: Latin America's reactive assemblies and proactive presidentes." In Legislative Politics in Latin America, edited by Scott Morgenstern and Benito Nacif, 446-468. Cambridge: Cambridge University Press.

Cranmer, Skyler J., and Bruce A. Desmarais. 2011. “Inferential Network Analysis with Exponential Random Graph Models." Political Analysis no. 19 (1):66-86.

Crisp, Brian F., Kristin Kanthak, and Jenny Leijonhufvud. 2004. “The Reputations Legislators Build: With Whom Should Representatives Collaborate." American Political Science Review no. 98 (4):703-716.

Cusak, Thomas R., Torben Iversen, and David Soskice. 2007. “Economic Interests and the Origins of Electoral Systems." American Political Science Review no. 101 (03):373-391. doi: doi:10.1017/S0003055407070384.

Díaz Cayeros, Alberto. 2006. Federalism, fiscal authority, and centralization in Latin America, Cambridge studies in comparative politics. Cambridge; New York: Cambridge University Press.

Engstrom, Erik J., and Samuel Kernell. 2005. “Manufactured Responsiveness: The Impact of State Electoral Laws on Unified Party Control of the Presidency and House of Representatives, 1840-1940." American Journal of Political Science no. 49 (3):531-549. doi: 10.1111/j.1540-5907.2005.00140.x.

Falleti, Tulia Gabriela. 2010. Decentralization and subnational politics in Latin America. New York: Cambridge University Press.

Fowler, James H. 2006. Connecting the Congress: A Study of Cosponsorship Networks.

Franzese, Robert J. 2002. Macroeconomic policies of developed democracies, Cambridge studies in comparative politics. Cambridge: Cambridge University Press.

Gellner, Ernest. 1983. Nations and nationalism. Ithaca: Cornell University Press.

Gervasoni, Carlos. 2010. "A Rentier Theory of Subnational Regimes: Fiscal Federalism, Democracy, and Authoritarianism in the Argentine Provinces." World Politics no. 62 (2):302-340.

Gibson, Edward. 1997a. “The Populist Road to Market Reform: Policy and Electoral Coalitions in Mexico and Argentina." World Politics no. 59 (N³):339-70.

Gibson, Edward L. 1997b. "The populist road to market reform: policy and electoral coalitions in Mexico and Argentina." World Politics (49):339-70.

. 2005. "Boundary Control: Subnational Authoritarianism in Democratic Countries." World Politics no. 58 (1).

Gibson, Edward L., Ernesto Calvo, and Tulia G. Falleti. 2004. “Reallocativefederalism: legislative overrepresentation and public spending in the Western Hemisphere." In Federalism and democracy in Latin America, edited by Edward L. Gibson, 173-196. Baltimore: The Johns Hopkins University Press.

Gibson, Edward L., and Julieta Suárez-Cao. 2007. Competition and power in federalized party systems. Working Paper No. 1, Program in Comparative Historical Social Science (CHSS), Northwestern University.

. 2010. “Federalized party systems and subnational party competition: theory and empirical application to Argentina." Comparative Politics no. 43 (1):21-39.

Gilligan, Thomas W., and Keith Krehbiel. 1994. "The Gains from Exchange Hypothesis of Legislative Organization." Legislative Studies Quarterly no. 19 (2):181-214.

Handcock, Mark S., David R Hunter, Carter T. Butts, Steven M. Goodreau, and Martina Morris. 2010. Statnet: Software tools for the Statistical Modeling of Network Data (Version 2.0. Project home page at http://statnetproject. org) 20032010]. Available from http://CRAN.R-project.org/package=statnet.

Harbers, Imke. 2010. “Decentralization and the Development of Nationalized Party Systems in New Democracies: Evidence From Latin America." Comparative Political Studies no. 43 (5):606-627. doi: 10.1177/0010414008330285.

Iversen, Torben, and David Soskice. 2006. Electoral Institutions and the Politics of Coalitions: Why Some Democracies Redistribute More Than Others. Cambridge Journals Online.

Jones, Mark P. 2005. The Role of Parties and Party Systems in the Policimaking Process. In State Reform, Public Policies, and Policymaking Processes. Washington D.C.

Jones, Mark P., and Wonjae Hwang. 2005. "Party Government in Presidential Democracies: Extending Cartel Theory Beyond the U.S. Congress." American Journal of Political Science no. 49 (2):267-83.

Jones, Mark P., and Scott Mainwaring. 2003. "The nationalization of politics: an empirical measure and an application to the Americas." Party Politics no. 9 (2):139-166.

Kawato, Sadafumi. 1987. "Nationalization and partisan realignment in congressional elections." American Political Science Review no. 81:1235-1250.

Lago-Peñas, Ignacio, and Santiago Lago-Peñas. 2009. “Does the nationalization of party systems affect the composition of public spending?" Economics of Governance no. 10:85-98.

Leiras, Marcelo. 2006. Parties, provinces and electoral coordination: a study on the determinants of party and party system aggregation in Argentina, 1983-2005. Ph.D. Dissertation, The Graduate School, University of Notre Dame.

. 2007a. Todos los Caballos del Rey. La Integración de los partidos políticos y el gobierno democrático de la Argentina,1995-2003. Buenos Aires: Prometeo.

- 2007b. Todos los caballos del rey: la integración de los partidos políticos y el gobierno democrático de la Argentina. Buenos Aires: Prometeo.

Levitsky, Steven. 2003. Transforming labor-based parties in Latin America : Argentine Peronism in comparative perspective. Cambridge, U.K. ; New York: Cambridge University Press. 
Lipset, Seymour Martin, and Stein Rokkan. 1967. Party systems and voter alignments: cross-national perspectives. Contributors: Robert R. Alford and others, International yearbook of political behavior research v. 7. New York,: Free Press.

Lodola, German. 2009. "La Estructura Subnacional de las Carreras Políticas en la Argentina y Brasil." Desarrollo Economico no. 49 (194):247-286.

Macor, Dario, and Cesar Tcach. 2005. La invencion del peronismo en el Interior del pais: Secretaria de Extension Universidad Nacional del Litoral: Santa Fe.

Mayhew, David. 1974. Congress: The Electoral Connection. New Haven: Yale University Press. 2000. "Electoral realignment." Annual Review of Political Science no. 3:449-474.

Micozzi, Juan Pablo. 2009. From House to Home: Linking Multi-Level Ambition and Legislative Performance in Argentina. In 67th MPSA Annual National Conference. Chicago, Illinois.

. 2013. “Does Electoral Accountability Make a Difference? Direct Elections, Career Ambition and Legislative Performance in the Argentine Senate." Journal of Politics no. Forthcoming.

Miller, Warren E., and Donald E. Stokes. 1962. "Party Government and the Salience of Congress." The Public Opinion Quarterly no. 26 (4):531-546.

. 1963. "Constituency Influence in Congress." The American Political Science Review no. 57 (1):45-56.

Morgenstern, Scott, and Stephen M. Swindle. 2005. “Are Politics Local?: An Analysis of Voting Patterns in 23 Democracies." Comparative Political Studies no. 38 (2):143-170.

Morgenstern, Scott, Stephen M. Swindle, and Andrea Castagnola. 2009. "Party Nationalization and Institutions." The Journal of Politics no. 71 (04):1322-1341. doi: doi:10.1017/S0022381609990132.

Pereira, Carlos, and Bernardo Mueller. 2004. "A theory of executive dominance of congressional politics: the committee system in the Brazilian chamber of deputies<sup $></$ sup $>$." Journal of Legislative Studies no. 10 $(1): 9-49$.

Robins, Garry, Pip Pattison, Yuval Kalish, and Dean Lusher. 2007. “An Introduction to Exponential Random Graph $\left(p^{*}\right)$ Models for Social Networks." Social Networks no. 29:173-191.

Rodden, Jonathan. 2010. "The Geographic Distribution of Political Preferences." Annual Review of Political Science no. 13:321-340.

Rokkan, Stein. 1970. Citizens, elections, parties; approaches to the comparative study of the processes of development, Comparative studies of political life, 1. New York,: McKay.

Rosas, Guillermo, and Joy Langston. 2011. "Gubernatorial Effects on the Voting Behavior of National Legislators." The Journal of Politics no. 73 (02):477-493. doi: doi:10.1017/S0022381611000326.

Samuels, David. 2003. Ambition, federalism, and legislative politics in Brazil. Cambridge ; New York: Cambridge University Press.

Shepsle, Kenneth A., and Barry R. Weingast. 1995. Positive theories of congressional institutions. Ann Arbor: University of Michigan Press.

Smith, Anthony. 1995. Nations and nationalism in a global era. Cambridge: Polity Press.

Stepan, Alfred. 2004. "Toward a New Comparative Analysis of Democracy and Federalism: Demos Constraining and Demos Enabling Federations." In Federalism and democracy in Latin America, edited by Edward L. gibson. Baltimore: Johns Hopkins University.

Tam Cho, Wendy K., and James H. Fowler. 2010. “Legislative Success in a Small World: Social Network Analysis and the Dynamics of Congressional Legislation." The Journal of Politics no. 72 (01):124-135. doi: doi:10.1017/ S002238160999051X.

Thorlakson, Lori. 2009. "Patterns of Party Integration, Influence and Autonomy in Seven Federations." Party Politics no. 15 (2):157-177. doi: 10.1177/1354068808099979.

Weingast, Barry. 1989. "Floor behavior in the U.S. Congress: committee power under the open rule." American Political Science Review no. 83 (3):795-815.

Ziblatt, Daniel. 2009. "Shaping Democratic Practice and the Causes of Electoral Fraud: The Case of NineteenthCenturyGermany." American PoliticalScience Reviewno.103(01):1-21. doi:doi:10.1017/S0003055409090042.

\section{Notas}

1 We thank Eduardo Aleman, Brian Crisp, Natalia del Cogliano, Marcelo Escolar, Sylvia Gaylor, Mariana Gutierrez, Scott Morgenstern, Flavia Freidenberg, Carlos Pereira and Mariana Pratt.

2 Jones (2005) notes that the nationalization of the party system shapes the legislative strategies (and ambition) of politicians, the policy-making behavior of state institutions, the ability of executives to forge coalitions, as well as the capacity of democracies to process ethnic and religious cleavages. While he notes that nationalized party systems are of critical importance in the enactment of legislation directed towards non-parochial goals, he does not measure the level of nationalization of policy-making.

3 A related strategy is the measure the level of nationalization of the legislator's ambition. Both Samuels (2003) and Micozzi (2009) have conducted research on the denationalization of progressive ambition in some Latin American cases. An attempt to measure provincial effects on the legislators' vote is in Jones and Hwang (2005) and more recently by Rosas and Langston (2011). 
4 They were mostly remnants of the so-called "concordancia" among Conservative Party and segments of the Union Civica Radical and the Socialist Party that prevailed in the notoriously fraudulent elections of the 1930s in Argentina.

5 Juan Pablo Micozzi (2010) analyzes the local or national orientation of legislators in Argentina, but rather than measure lawmaking collaboration, he instead focuses on policy targets. For a very interesting analysis of legislative targeting in a non-federal country, see the recent work of Chasquetti and Micozzi (2012).

6 We thank an anonymous reviewer and the editor for highlighting this issue.

7 Beginning in 1984, a significant increase in the number of legislative initiatives proposed to Congress led to increased network density until 2001. Since then, a decline of legislative collaboration after 2003 is consistent with changes in legislative behavior by the new Peronist administration of Nestor Kirchner, characterized by a more centralized and confrontational legislative bloc policy -in an attempt to secure control of the party - and accompanied by significant legislative fragmentation among opposition parties.

8 This summary of ERGM modeling is based on Robins et al. (2007) and Handcock et al. (2008).

9 See Goodreau et al. (2008, pp. 7-8).

10 Valued matrices are RxC matrices with their diagonal describing the total number of ties by each individual $i$ $i$ and off diagonal elements describing the count of ties between each pair of individuals $[i, j]$.

11 For references see Calvo and Aleman (2010).

12 Namely parties that compete in only one or just a few provincial districts.

13 These tables are available upon request. 